\title{
PEMAHAMAN SYAIR TEMBANG LIR-ILIR KARYA SUNAN KALIJAGA DALAM PEMBELAJARAN IPS PADA SISWA KELAS VII B SMP KRISTEN SATYA WACANA SALATIGA
}

\author{
Daniel Zafnat Paaneah \\ Program Studi Pendidikan Sejarah FKIP UKSW \\ 152016601@student.uksw.edu \\ Sunardi \\ Program Studi Pendidikan Sejarah FKIP UKSW \\ sunardi.sunardi@uksw.edu \\ Emy Wuryani \\ Program Studi Pendidikan Sejarah FKIP UKSW \\ emy.wuryani@uksw.edu
}

\begin{abstract}
Song Lir-ilir is one of the legacies in the form of music art in the time of Islam by Sunan Kalijaga, which at that time was used as a media to spread Islam. In social studies learning, on 7th grade junior high school has material about the period of Islam in Indonesia which is the material also discusses the relics of the Islamic period in Indonesia. But students do not yet know that Lir-ilir song is one of them and play an important role in the process of Islamization in Indonesia and meaning that are able to educate students's character. The purpose of this study is to explain students's understanding, character arising and the effect of Lir-ilir songs on students. This research was carried out on students 7 th grade Class B of SMP Kristen Satya Wacana Salatiga 2nd semester year of 2018/2019, totaling 22 students. In the pre-test of this study students got an average of 7.9 which can be concluded that students do not understand or recognize Lir-ilir songs. In learning students are taught about the meaning and understanding of the song that teaches the value of tolerance and mutual respect, for fellow examples in the scope of the school; bullying, etc. Students also learned to sing Lir-ilir song in front of the class in groups. On the post-test average value of students's understanding increases to 90 so it can be concluded that students become undestand of the song Lir-ilir.
\end{abstract}

Keywords: islamization of Java, lyric of song Lir-ilir, understanding

\section{PENDAHULUAN}

Sunan Kalijaga menjadi salah satu tokoh Walisongo yang paling dikenal terutama di Jawa karena metode dakwahnya yang berbeda dari tokoh Walisongo yang lain. Dalam berbagai cerita, Sunan Kalijaga juga digambarkan sebagai satu-satunya wali yang paling kritis, memilki sikap toleransi yang tinggi, dan memilki pandangan yang jauh (Mujiningsih, 2015). Sunan Kalijaga juga dikenal sebagai sosok yang memiliki karisma dan juga ilmu yang tinggi dalam meneladani agama Islam (Said, 2013). Hariwijaya (2008), menyatakan bahwa Sunan Kalijaga merupakan satu-satunya sunan yang berdarah Jawa dan menggabungkan seni dan budaya Jawa dalam dakwahnya sehingga dapat diterima dengan mudah oleh masyarakat Jawa pada masa itu. Beberapa peninggalan seni dari Sunan Kalijaga yang masih dikenal hingga sekarang diantaranya lagu Lingsir Wengi, Kidung Rumeksa Ing Wengi, Turi-turi Putih, Lir-Ilir, dan lain-lain. Ia juga menyatakan bahwa Sunan Kalijaga mengarang tembang Lir-ilir dengan maksud untuk mengingatkan 
orang melalui agama yang dianut dan rusak harus segera diperbaiki sebagai bekal menghadap Tuhan selagi orang masih hidup.

Dalam dunia pendidikan, syair tembang Lir-ilir ini sarat makna dalam penanaman nilai-nilai karakter yang terkandung didalamnya, mulai dari aspek agama, sosial, pendidikan bahkan kepribadian. Hal itu sebenarnya sudah terlulis dalam UU No. 20 Pasal 3 tahun 2003 mengenai SISDIKNAS yang memiliki fungsi sebagai pengembang kemampuan dan membentuk watak serta karakteristik dan peradaban bangsa agar siswa menjadi manusia yang beriman serta taqwa kepada Tuhan Yang Maha Esa, memiliki akhlak mulia, sehat jasmani dan rohani, cakap ilmu, keratif, mandiri dan bertanggung jawab.

Permasalahan yang terjadi dalam dunia pendidikan di Indonesia saat ini adalah aspek pendidikan karakter yang belum dirinci dengan jelas pada undang-undang tersebut sehingga belum ada implementasi yang nyata terkait penanaman pendidikan karakter di sekolah. Berbagai kasus bermunculan yang tidak sesuai dengan moralitas, sopan santun, unggah-ungguh yang berlaku di masyarakat, seperti: pemukulan terhadap guru dan pegawai sekolah yang dilakukan siswa, merokok di lingkungan sekolah dan bersikap acuh tak acuh terhadap guru dan pegawai sekolah. Penanganan pendidikan karakter ini menjadi serius apabila tidak dilakukan upaya dalam menanamkan nilai-nilai yang dapat memperkuat karakter siswa. Apabila tidak ditangani secara serius dimungkinkan mengakibatkan timbul karakter siswa yang berontak, dan tidak menghargai satu sama lain.

Salah satu alternatif penerapan nilai-nilai pendidikan karakter bagi siswa dapat dilakukan melalui pemahaman sebuah syair lagu atau tembang yang dikenalkan oleh Sunan Kalijaga dalam melakukan proses Islamisasi di Jawa. Tembang Lir-ilir merupakan salah satu bagian dari pokok bahasan materi kelas VII B SMP Kristen Satya Wacana Salatiga Semester Genap Bab ke-4 tentang Kehidupan Masyarakat Pada Masa Islam yang didalamnya membahas tentang peninggalan-peninggalan pada masa Islam di Indonesia.

Selama ini pemahaman mengenai lagu atau tembang daerah belum intensif dikenalkan oleh guru kepada siswa di SMP Kristen Satya Wacana Salatiga, hanya beberapa kali diajarkan dalam mata pelajaran Seni ataupun ekstrakurikuler Karawitan, namun hanya digunakan sebagai panduan/materi dalam memainkan gamelan. Padahal banyak makna dan teladan yang dapat diperoleh oleh siswa melalui tembang-tembang daerah seperti salah satunya tembang Lir-ilir. Melalui pengamatan peneliti, karakter yang paling terlihat dalam kelas VII B SMP Kristen Satya Wacana tersebut adalah melakukan perundungan/bullying terhadap teman yang dianggap berbeda atau tidak memiliki pemikiran yang sama dengan teman yang lain. Untuk perilaku yang diberikan oleh siswa kelas kepada guru adalah cenderung mengabaikan dan tidak fokus terhadap materi yang diajarkan oleh guru selama proses pembelajaran.

Oleh karena itu perlu adanya pemahaman tentang nilai-nilai karakter yang terkandung dalam salah satu peninggalan pada masa Islam di Indonesia berupa tembang Lir-ilir yang didalamnya terdapat nilai-nilai pendidikan karakter. Pada penelitian ini tahapan pemahaman yang akan diambil merupakan bagian dari menafsirkan, dimana siswa diharapkan dapat mengenal dan memahami nilai-nilai karakter yang terkandung dalam syair tembang Lir-ilir. Mengacu pada permasalahan di atas maka peneliti ingin menerapkan pengenalan dan pemahaman syair tembang Lir-ilir kepada siswa kelas VII B SMP Kristen Satya Wacana Salatiga Semester Genap TA 2018/2019. Harapannya adalah setelah mempelajari dan memahami mengenai syair tembang Lir-ilir siswa mampu menerapkan nilai-nilai karakter yang terkandung dalam tembang Lir-ilir tersebut. 
Berdasarkan latar belakang yang telah dirinci di atas maka rumusan masalah penelitian ini adalah bagaimana pemahaman siswa Kelas VII B SMP Kristen Satya Wacana Salatiga terhadap syair tembang Lir-ilir. Tujuan dari penelitian ini adalah menjelaskan mengenai pemahaman siswa kelas VII B SMP Kristen Satya Wacana Salatiga terhadap syair tembang Lir-ilir.

\section{TINJAUAN PUSTAKA}

\section{Sunan Kalijaga}

Sunan Kalijaga merupakan sebutan yang disematkan kepada Raden Sahid, putra dari Tumenggung Wilawatikta (Aria Teja IV), Bupati Tuban pada sekitar tahun $1450 \mathrm{M}$. Tumenggung Wilawatikta adalah keturunan Patih Ranggalawe (Raden Sahur) dari Kerajaan Majapahit yang beragama Islam (Sofwan, 2000). Raden Sahid disebut sebagai "maling budiman" pada masa Majapahit karena kerap merampok orang-orang kaya yang korup dengan cara membajaknya di dalam hutan. Hasil pembajakannya tersebut diberikan kepada masyarakat yang miskin. Gelar Sunan yang diterima oleh Raden Sahid didasarkan atas tingkah lakunya yang baik, sopan santun, berbudi luhur, dan hidup dengan penuh kebajikan menurut tuntunan agama Islam (Sofwan, 2000).

Sunan Kalijaga adalah satu di antara Walisongo dan melakukan dakwah mengenai ajaran agama Islam ke berbagai penjuru daerah. Para bangsawan, agamawan, budayawan, dan masyarakat di wilayah pedesaan berguru kepada Walisongo. Wulangan, wejangan, dan wedharan yang disampaikan oleh Sunan Kalijaga senantiasa berusaha menjaga keselarasan antara agama dan budaya. Akulturasi teks keagamaan dengan wacana kebudayaan melahirkan kearifan lokal yang mampu menciptakan suasana harmonis dalam kehidupan masyarakat Jawa. Peralihan dari adat lama menuju kehidupan baru yang bernuansa Islam tetap berjalan secara aman, tentram dan damai, tanpa menimbulkan kegoncangan. Berkaitan dengan ajaran budi pekerti dijelaskan pula mengenai pengendalian diri, toleransi, dan sifat kemanusiaan (Hafidz, 2015).

Seni menjadi media dakwah yang digunakan oleh Sunan Kalijaga untuk menyebarluaskan ajaran Islam. Media seni yang digunakan antara lain seni pakaian, seni suara, seni ukir, seni gamelan, dan wayang dengan karakter Punakawan seperti Semar yang sabar, bijaksana dan taat beragama, Petruk yang dapat dipercaya dan peduli terhadap sesama, Gareng yang selalu berhati-hati dalam bersikap dan menghindari konflik dengan sesama, serta Bagong yang selalu jujur, bijak dan toleran (Slamet Muljana, 2005).

\section{Lir-ilir}

Lir-ilir merupakan tembang Jawa yang menjadi media bagi Sunan Kalijaga untuk berdakwah mengenai ajaran agama Islam kepada masyarakat pada sekitar abad ke 15 di tengah perkembangan pesat agama Hindu dan Budha khususnya di tanah Jawa. Tembang ini pada masa sekarang umumnya dinyanyikan oleh anak-anak ketika sedang bermain. Bagi orang dewasa, tembang ini kerap dianggap sebagai tembang kenangan berbahasa Jawa yang mengingatkan seseorang tentang kegiatan bermain dan kebersamaan di masa kecil, namun tidak memaknai arti dari tembang tersebut. Makna utama tembang Lir-ilir adalah mengajak masyarakat untuk menjalani hidup dengan lebih taat kepada penciptaNya, memaksimalkan kehidupan untuk ma'rifat bil Allah (mengenal Allah secara mendalam), tidak hanya sekedar untuk mengajak masyarakat agar memeluk agama Islam (Ahmad Chodjim, 2003). Makna yang tersirat di dalam tembang Lir-ilir secara keseluruhan adalah tentang keimanan dalam agama Islam, yakni rukun Islam, hal 
pertobatan, muhasabah (memahami diri sendiri tentang kebaikan dan keburukan yang telah diperbuat), serta memperbaiki kesalahan selagi masih ada waktu dimasa sekarang sebelum ajal menjemput.

\section{Pendidikan Karakter}

Agus Prasetyo \& Emusti Rivasintha (2011) mengemukakan bahwa pendidikan karakter merupakan sistem penanaman nilai-nilai karakter kepada siswa yang didalamnya meliputi unsur-unsur pengetahuan, kemauan, kesadaran untuk melaksanakan nilai-nilai tersebut, kepada Tuhan, diri sendiri, sesama manusia, lingkungan sekitar maupun kebangsaan. Nilai-nilai dalam pendidikan karakter tersebut antara lain; religius, jujur, toleransi, disiplin, kerja keras, kreatif, mandiri, demokratis, rasa ingin tahu, semangat kebangsaan, cinta tanah air, menghargai prestasi, bersahabat dan atau komunikatif, cinta damai, gemar membaca, peduli lingkungan, peduli sosial, dan tanggung jawab. Dengan demikian, nilai-nilai dalam pendidikan karakter tidak hanya dipahami secara kognitif, namun juga bagaimana dalam siswa dalam mengimplementasikannya ketika hidup bermasyarakat (Siswati, Utomo dan Muntholib: 2018).

\section{Pemahaman}

Benjamin S. Bloom (2009) mengemukakan bahwa pemahaman/komperhensi (Comperhension) merupakan kemampuan individu dalam mengerti atau memahami suatu hal setelah hal tersebut diketahui dan diingat dalam pikiran seorang individu. Memahami berarti mengerti tentang sesuatu dan dapat melihatnya dari berbagai sudut pandang. Oleh karenanya dari itu dapat disimpulkan bahwa peserta didik dapat dikatakan paham jika peserta didik tersebut dapat memberikan penjelasan atau uraian yang lebih rinci perihal yang dipahaminya dengan menggunakan bahasanya sendiri.

Tingkatan yang lebih diatasnya adalah jika peserta didik juga dapat memberikan contoh konkrit dengan hal-hal yang ada di sekitarnya. Peserta didik dituntut untuk dapat memahami apa yang telah diajarkan, dan mengerti hal apa saja yang sedang dikomunikasikan. Sedangkan tingkatan dalam pemahaman terdiri atas tiga yakni menerjemahkan, menafsirkan dan mengekstrapolasi. Menerjemahkan merupakan pengalihaan atas satu bahasa terhadap bahasa lain atau konsep abstrak menjadi suatu hal simbolik untuk mempermudah orang dalam memahaminya, misalnya dalam mengartikan kalimat Ing Ngarsa Sung Tuladha. Menafsirkan yaitu kemampuan dalam hal mengenal suatu hal dan memahaminya. Tahapan ini dapat dilakukan dengan cara menghubungkan pengetahuan-pengetahuan di masa lalu dengan pengetahuan-pengetahuan yang diperoleh pada masa berikutnya. Mengekstrapolasi merupakan tahapan yang lebih tinggi, seseorang dituntut untuk dapat membuat ramalan hasil sebab - akibat, memperluas kemampuan persepsi dalam waktu, dimensi, kasus dan masalah-masalah yang lainnya. Pada tahapan pemahaman untuk penelitian ini, peneliti mengambil pada tahapan pertama yaitu menerjemahkan, supaya siswa yang semulanya tidak mengenal dan paham, setelah mempelajari dan memahami syair tembang Lir-ilir dapat menerjemahkan, memahami secara mendalam, dan menerapkan nilai-nilai karakter pada tembang tersebut.

\section{METODE PENELITIAN}

Penelitian ini tergolong dalam penelitian pendidikan deskriptif kualitatif. Subjek penelitian adalah siswa-siswi kelas VII B SMP Kristen Satya Wacana semester Genap, Tahun Ajaran 2018/2019. Jumlah siswa 22 orang, yang terdiri dari 12 putera dan 10 
puteri. Penelitian dilakukan dalam 2 kali pertemuan dengan durasi jam pelajaran masing masing 2 x 40 menit. Sumber data diperoleh di perpustakaan Universtitas Kristen Satya Wacana, perpustakaan pribadi, e-journal dan observasi. Data diperoleh dengan cara kajian pustaka, observasi, partisipasi langsung, pemberian tugas dan hasil tes. Teknik pengumpulan data melalui observasi, partisipasi dan kajian

Validitas data menggunakan teknik triangulasi data. Teknik analisa data yang digunakan analisis deskriptif kualitatif dengan penerapan Best Practice. Media penelitian berupa; lembar bacaan tembang Lir-ilir, Power Point, MP3 tembang Lir-ilir, LCD dan speaker. Instrumen penelitian yang digunakan yaitu (1) tes tertulis berupa pre-test dan post-test, (2) keaktifan siswa dalam mengikuti proses pembelajaran, (3) Lembar Observasi Guru, (4) Lembar Observasi Siswa, dan (5) dokumentasi bentuk foto menggunakan kamera handphone.

\section{HASIL PENELITIAN DAN PEMBAHASAN}

Pertemuan pertama pada Rabu 27 Maret 2019 pukul 07.30 - 08.10 WIB peneliti melakukan pengajaran tentang materi Kehidupan Masyarakat Pada Masa Islam (Bab C. KD 5.2) dengan jumlah siswa 22. Pembelajaran menggunakan model pembelajaran Discovery Learning dengan metode Diskusi. Pembelajaran dimulai dengan peneliti menjelaskan tujuan pembelajaran, tentang proses masuknya Islam ke Indonesia, persebaran Islam di Indonesia, pengaruh Islam terhadap masyarakat di Indonesia, kerajaan-kerajaan Islam di Indonesia dan peninggalan sejarah masa Islam di Indonesia. Peneliti juga menyajikan gambar-gambar pada power point yang relevan dengan materi tersebut. Sebelum mengakhiri pembelajaran untuk mengukur pemahaman siswa mengenai tembang Lir-ilir peneliti memberikan pre-test pada siswa dalam bentuk 4 pertanyaan essay yang masing-masing memiliki bobot nilai 25 . Pertanyaan tersebut antara lain: (1) apa itu Walisongo?, (2) siapa saja Walisongo tersebut?, (3) siapakah Sunan Kalijaga?, dan (4) apakah Anda tahu/pernah mendengar tembang Lir-ilir? (Ya/Tidak) Jika Ya tuliskan syairnya! Hasil dari pre test dengan rincian sebagai berikut:

Tabel 1

Hasil Pre Test

\begin{tabular}{cccc}
\hline Rentang Nilai & Jumlah Siswa & Persentase (\%) & Ketuntasan \\
\hline $\mathbf{0}-\mathbf{2 4}$ & 15 & 68,2 & Belum Tuntas \\
$\mathbf{2 5}-\mathbf{4 9}$ & 6 & 27,3 & Belum Tuntas \\
$\mathbf{5 0}-\mathbf{7 1}$ & 1 & 4,5 & Belum Tuntas \\
$\mathbf{7 2}-\mathbf{1 0 0}$ & - & 0 & Tuntas \\
Total & $\mathbf{2 2}$ & $\mathbf{1 0 0}$ & \\
\hline
\end{tabular}

Pada tabel 1 diatas, hasil pre-test dapat diketahui bahwa seluruh siswa tidak memahami atau mengenal tembang Lir-ilir dengan indikasi hasil bahwa seluruh siswa tidak mencapai KKM yang ditetapkan oleh sekolah yaitu 72, bahkan 15 siswa mendapatkan nilai 0 sedangkan hanya 1 siswa yang hampir mencapai KKM dengan mampu menjawab 2 pertanyaan dan sisanya hanya mampu menjawab 1 pertanyaan saja. Dari hasil tersebut dapat diketahui bahwa pada pembelajaran IPS belum diajarkan secara mendalam sehingga siswa tidak mengetahui bahwa tembang Lir-ilir juga merupakan 
bagian dari materi yang diajarkan tersebut, karena terkendala oleh banyaknya materi yang harus diajarkan pada siswa dengan jam pelajaran yang terbatas.

Pertemuan kedua dilakukan pada Jumat 5 April 2019 pukul 09.50 - 10.30 WIB. Peneliti melanjutkan materi Kehidupan Masyarakat Pada Masa Islam (Bab C KD 5.2) jumlah siswa 20 dan 2 siswa absen. Pembelajaran menggunakan model Discovery Learning dan metode Diskusi, dengan fokus mengenai Walisongo, Sunan Kalijaga dan tembang Lir-ilir. Pada awal pembelajaran peneliti menjelaskan mengenai tujuan dari pembelajaran pada pertemuan tersebut. Peneliti menyajikan gambar Walisongo pada Power Point dan menjelaskan siapa saja yang termasuk dalam Walisongo tersebut. Pada slide selanjutnya peneliti menyertakan gambar Sunan Kalijaga dan menjelaskan tentang siapa Sunan Kalijaga dan menyebutkan hasil karya Sunan Kalijaga yang menjadi peninggalan pada masa Islam hingga saat ini dan salah satunya adalah tembang Lir-ilir. Pada proses selanjutnya peneliti membagi siswa dalam bentuk kelompok dengan jumlah 5 kelompok dan masing-masing terdiri dari 4 siswa. Peneliti kemudian membagikan lembar literasi pada masing-masing siswa yang didalamnya merupakan syair tembang Lir-ilir berikut dengan artiannya dalam bahasa Indonesia. Setelah diberikan waktu untuk membaca selama 10 menit selanjutnya peneliti menjelaskan mengenai makna dan artian syair tembang Lir-ilir. Peneliti menjelaskan mengenai artian syair yang mengandung makna tentang toleransi, saling menghormati kepercayaan satu sama lain dan menghargai antara satu sama lain untuk menghindari terjadi konflik dan perselisihan dimana dalam mengajarkan agama Islam melalui salah satu medianya tembang Lir-ilir Sunan Kalijaga tidak menggunakan paksaan dan bersifat terbuka.

Proses selanjutnya peneliti memutarkan $M P 3$ tembang Lir-ilir dan siswa diminta untuk memperhatikan dan menirukan dalam hati. Pada pemutaran yang kedua, peneliti memberikan contoh pada siswa untuk menyanyikan tembang tersebut. Selanjutnya siswa dan peneliti menyanyikan tembang Lir-ilir bersama-sama sebanyak 3 kali sampai siswa paham dan dapat menyanyikan tembang Lir-ilir. Pada kegiatan selanjutnya peneliti meminta siswa untuk menyanyikan tembang Lir-ilir berkelompok secara bergantian di depan kelas tanpa panduan dari peneliti dan setiap kelompok berhasil melakukan hal tersebut.

Pada kegiatan inti peneliti me-review hasil dari pembelajaran yang disesuaikan dengan tujuan pada awal pembelajaran. Peneliti kembali menekankan mengenai pentingnya toleransi dan saling menghargai antar sesama, bahkan ada siswa yang terbuka meminta maaf kepada siswa yang lain karena dalam keseharian di sekolah melakukan sikap perundungan (bully) terhadap siswa yang lainnya. Pada akhir pembelajaran peneliti memberikan post-test dengan 4 soal yang sama dengan pre-test untuk mengetahui hasil dari pembelajaran dengan rincian hasil sebagai berikut:

Tabel 2

Hasil Post Test

\begin{tabular}{llll} 
Rentang Nilai & Jumlah Siswa & Persentase (\%) & Ketuntasan \\
\hline
\end{tabular}




\begin{tabular}{cccc}
\hline $\mathbf{0}-\mathbf{2 4}$ & - & - & \\
$\mathbf{2 5}-\mathbf{4 9}$ & - & - & \\
$\mathbf{5 0}-\mathbf{7 4}$ & - & - & \\
$\mathbf{7 5}-\mathbf{8 4}$ & 8 & 40 & Tuntas \\
$\mathbf{8 5}-\mathbf{1 0 0}$ & 12 & 60 & Tuntas \\
Total & $\mathbf{2 0}$ & $\mathbf{1 0 0}$ & \\
\hline
\end{tabular}

Pada tabel 2 diatas, hasil post-test menunjukkan 8 siswa mendapat nilai 75 dengan berhasil menjawab 3 pertanyaan, 12 siswa mendapatkan nilai 100 dengan berhasil menjawab 4 pertanyaan, sedangkan 2 siswa tidak diketahui nilainya karena tidak hadir dalam pembelajaran. Pada hasil tersebut dapat dilihat bahwa kenaikan nilai yang sangat signifikan dari hasil rata-rata awal yang hanya 7.9 menjadi 90 . Nilai tertingggi pertemuan pertama adalah 50 pada pertemuan kedua naik menjadi 100 dan nilai terendah adalah 0 , naik menjadi 75, sehingga dapat disimpulkan bahwa siswa telah memahami tentang tembang Lir-ilir tersebut. Pemahaman mengenai nilai karakter juga muncul dengan respon awal siswa yang mengerti nilai-nilai karakter pada syair tembang Lir-lir tersebut terkait nilai toleransi dan menghargai sesama pada saat siswa yang melakukan perundungan (bully) mampu memahami perbuatan dan meminta maaf pada siswa yang dirundung (bully).

\section{SIMPULAN}

Berdasarkan hasil penelitian diatas dapat disimpulkan bahwa (1) siswa menjadi paham tentang tembang Lir-ilir, hal ini dapat dilihat dari hasil pre-test dan post-test yang meningkat secara signifikan dari total rata-rata nilai yang hanya 7.9 menjadi 90 . Dapat digambarkan bahwa siswa yang semulanya sama sekali tidak mengetahui tentang tembang Lir-ilir kini menjadi paham sekaligus mengerti siapa pencipta, maksud dan tujuan diciptakan tembang Lir-ilir tersebut. Saran kepada sekolah terutama pengampu mata pelajaran IPS atas penelitian ini adalah pembelajaran tentang tembang-tembang daerah perlu digiatkan, karena sarat akan makna-makna yang dapat mengembangkan karakter dan kepribadian siswa. Selain itu pembelajaran tentang tembang-tembang daerah juga sangat berperan aktif dalam pelestarian kebudayaan daerah dan juga menambah pengetahuan siswa tentang keberagaman dan kekayaan budaya yang ada di Indonesia.

\section{DAFTAR PUSTAKA}

Achidisti, S. A. (2012). Strategi Penyebaran Islam Pada Masyarakat Jawa. Jurnal Kebudayaan Islam.Vol. 10, No. 2, Juli-Desember 2012: hal 199.

Bloom, B. S. (1979). Taxonomy of Educational Objective. New York: Longman

Chodjim, A. (2003). Sunan Kalijaga Mistik dan Makrifat. Jakarta: PT Serambi Ilmu Semesta.

Hafidz, M. (2015). Peranan Sunan Kalijaga dalam Islamisasi di Jawa Tahun 1470 1580. Jember: Artikel Ilmiah Mahasiswa Universitas Jember.

Hariwijaya, M. (2008). Sunan Kalijaga, Waliyullah Tanah Jawi. Depok: PT. Visi Gagas Komunika. 
Muhsin, R. J., Elah N. (2013). Peningkatan Kemampuan Pemahaman Dan Pemecahan Masalah Matematis Melalui Pembelajaran Dengan Pendekatan Kontekstual. Jurnal Peluang, Volume 2, Nomor 1, Oktober 2013: hal. 1.

Mujiningsih. (2015). Sunan Kalijaga Dalam Novel Babad Walisongo, Wali Sanga, Dan Kisah Dakwah Wali Songo. Jurnal Bahasa dan Seni. Vol. 43, No 2: hal 217.

Muljana, S. (2005). Runtuhnya Kerajaan Hindu - Jawa dan Timbulnya Negara-negara Islam di Nusantara. Yogyakarta: LKIS Yogyakarta.

Novtasari, M. (2018). Metode Dakwah Dengan Pendekatan Kultural Sunan Kalijaga. Undergraduate Thesis, repository UIN Raden Intan Lampung.

Prasetyo, A. dan Emusti R. (2011). Konsep Urgensi dan Implementasi Pendidikan Karakter di Sekolah. Jakarta: Artikel Elektronik Kompasiana.

Said, N. (2013). Urgensitas Cultural Sphere Dalam Pendidikan Multikultural: Rekonstruksi Semangat Multikulturalisme Sunan Kudus Bagi Pendidikan Multikultural Di Stain Kudus. ADDIN, Vol. 7, No. 1, Februari 2013: hal. 19.

Siswati, Cahyo B. U., dan Abdul M. (2018). Implementasi Pendidikan Karakter dalam Membentuk Sikap dan Perilaku Sosial Peserta Didik Melalui Pembelajaran Sejarah di SMA PGRI 1 Pati Tahun Pelajaran 2017/2018. Indonesian Journal of History Education. Vol 6, Januari 2018: hal. 1-13.

Sofwan, R. (2000). Islamisasi di Jawa: Walisongo, Penyebar Islam di Jawa, Menurut Penuturan Babad. Yogyakarta: Pustaka Pelajar.

Undang-undang No. 20 Pasal 3 Tahun 2013 tentang Sistem Pendidikan Nasional. 